\title{
Early growth, lipid composition, and survival expectations of shrimp Pandalus borealis larvae in the northern Gulf of St. Lawrence
}

\author{
Patrick Ouellet ${ }^{1, *}$, Christopher T. Taggart ${ }^{2}$, Kenneth T. Frank $^{3}$ \\ ${ }^{1}$ Ministère des Pêches et des Océans, Institut Maurice-Lamontagne, CP 1000, 850 route de la mer, Mont-Joli, Québec, \\ Canada G5H 3 Z4 \\ ${ }^{2}$ Department of Fisheries and Oceans, Northwest Atlantic Fisheries Centre, PO Box 5667, White Hills, St. John's, \\ Newioundland, Canada A1C 5X1 \\ ${ }^{3}$ Department of Fisheries and Oceans, Bedford Institute of Oceanography, PO Box 1006, Dartmouth,
} Nova Scotia, Canada B2Y 4A2

\begin{abstract}
Shrimp Pandalus borealis larval abundance, early growth, and lipid composition were assessed at 3 sites in the northern Gulf of St. Lawrence, Canada, in May 1990. Physical characteristics (temperature, salinity, beam attenuation) of the water column, zooplankton biomass (80 to $250 \mu \mathrm{m}$ and $333 \mu \mathrm{m}$ to $2 \mathrm{~mm}$ size fractions) and its taxonomic composition ( $333 \mu \mathrm{m}$ to $2 \mathrm{~mm}$ size fraction) at each site, were also investigated. The 3 sampling sites were different environments with distinct water column characteristics and zooplankton community structures. Phospholipids were the most abundant $(\sim 80 \%)$ lipid class in shrimp zoea I and zoea II larvae whereas the triacylglycerols (TAG) accounted for an average of $5 \%$ of the total lipids. The distribution of TAG wet-weight ratios of shrimp larvae captured in the field was similar to laboratory reared larvae, suggesting that the laboratory-derived TAG condition index can be used to infer the performance of shrimp larvae in different environments and to estimate relative survival expectations among the larval cohorts. In general, shrimp larvae were apparently not suffering from limited food resources in the sectors of the Gulf in 1990. Nevertheless, zoea II larvae were larger in size (weight) and length, and showed a higher TAG condition index at the sites where developmental stages of calanoid copepods were more abundant. This supports the proposition that secondary production in the water column influences growth, condition, and survival potential of shrimp larvae. It is proposed that survival of the first larval stage and recruitment to the shrimp stocks are influenced by the factors affecting stratification and mixing in the water column, i.e. buoyancy fluxes, through contral of phytoplankton and copepod production in the northern Gulf of St. Lawrence.
\end{abstract}

KEY WORDS: Pandalus borealis - Larvae - Survival - Secondary production Gulf of St. Lawrence

\section{INTRODUCTION}

It is generally accepted among fisheries biologists that factors (mainly fluctuations in the abiotic environment) affecting growth and survival during the early life stages influence the level of recruitment to marine populations (Shepherd et al. 1984, Laurence 1990). Moreover, small changes in growth and mortality during the early stages can have a profound effect on the fluctuations in the number of recruits (Laurence 1990,

·E-mail: p_ouellet@qc.dfo.ca
Fogarty et al. 1991j. Most attempts to correlate early larval abundance or mortality (or proxies thereof) with a simple environmental signal have been inconclusive or existing relations frequently fail when new data are added to the analyses (Taggart \& Frank 1990). Taggart \& Frank (1990) also argued that it is first necessary to resolve the biological processes at and below the scale of the driving physical processes to succeed in identifying the relationships between environment and recruitment level. Thus, a more precise definition of the primary ecological factor(s) that directly influence larval growth and survival could be an effective means 
to achieve a better recruitment prediction. The use of a biochemical (lipid-based) condition index that reflects the survival potential of the larvae may prove to be a powerful tool in assessing the ecological factor(s) involved (Ouellet et al. 1992).

There are 3 principal Pandalus borealis aggregations in the northern Gulf of St. Lawrence, Canada. the northwest, north Anticosti, and northeast sectors (Fig. 1). In spring, adult female shrimp move toward shallower water where the first pelagic larval stage is released into the water column. Larval emergence has been reported to occur simultaneously from April to early May within each sector of the northern Gulf (Ouellet et al. 1990). The study of the pattern and scale of shrimp larval horizontal distribution showed a spatially structured distribution of zoea I larval patches following emergence in the sectors of the northern Gulf, but a spatially random pattern of distribution with no clear relationship with the hydrographic spatial heterogeneity for the older larvae within the different sectors (Ouellet et al. 1990). It was therefore hypothesized that differential developmental rates and mortality, in response to trophic variability within the sectors, may explain the spatial pattern of distribution of the older (zoea II+) shrimp larvae (Ouellet et al. 1990). A subsequent study on the vertical distribution of shrimp larvae revealed that the zoeae I and II aggregate near the pycnocline (above $40 \mathrm{~m}$ ) in a stratified water column, coincident with high chlorophyll a (chl a) and suspended particle concentrations (Ouellet \& Lefaivre 1994). In addition, the direction and magnitude of water transport were favorable for the maintenance of larval shrimp cohorts within the northwest sector of the Gulf (Ouellet \& Lefaivre 1994).

This study is a component of the research program on Pandalus borealis larval distribution and ecology in

the northern Gulf of St. Lawrence. The specific objectives were: (1) to measure and compare abundance. growth, and lipid composition of shrimp larvae at different sites (water masses) in 2 sectors of the northern Gulf, and (2) to assess the utility of a laboratoryderived lipid condition index (i.e. larval triacylglycerols (TAG) content $(\mu \mathrm{g})$ : wet weight $(\mathrm{mg})$ ratio (TAG $\left.w w^{-1}\right) \times 1000$; Ouellet et al. 1992] for estimating larval survival potential in the field. The variability observed in shrimp larval growth, lipid condition, and survival potential among the sampling sites is discussed in relation to the differences in water mass characteristics (physical and biological) observed among the sites.

\section{MATERIALS AND METHODS}

The study was conducted at 3 sites in the northern Gulf of St. Lawrence between 24 May and 2 June 1990 (Fig. 1). Sites A and B were located in the northwest Gulf, in the principal zone of larval emergence observed for the northwest sector (Ouellet et al. 1990). Site $C$ was located $\sim 5 \mathrm{~km}$ from the north coast of Anticosti Island, in the zone of larval emergence for the north Anticosti sector (Ouellet et al. 1990). Each site was described by a fixed $20 \times 20 \mathrm{~km}$ 12-station grid (Fig 1). The entire grid at each site was sampled within $24 \mathrm{~h}$ and each grid was sampled twice (circuit 1 and circuit 2) before moving to the next site.

At each grid station, vertical temperature, salinity and light transmission [Sea Tech $25 \mathrm{~cm}$ beam $(660 \mathrm{~nm})$ transmissometer] profiles were recorded. Underwater light transmission was converted to a beam attenuation coefficient $a\left(\mathrm{~m}^{-1}\right)$ according to Lieberman et al. (1984):

$$
a=\frac{-\ln T}{0.25}
$$

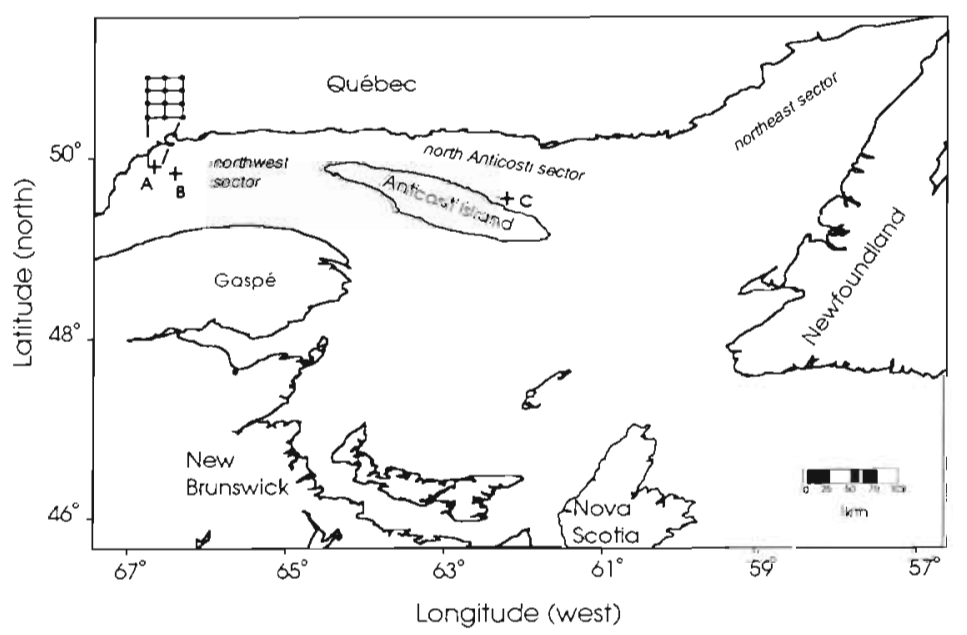

Fig. 1. Position of the sampling sites and details of the sampling grid for each site in the northern Gulf of St. Lawrence, May 1990 where $T$ is the relative light transmission at depth and 0.25 is the length $(\mathrm{m})$ of the instrument light path. Continuous downcast profiles of temperature, density $\left(\sigma_{t}\right)$, and beam attenuation were averaged at $1 \mathrm{~m}$ intervals and subsequently smoothed using a 5 point moving average.

Vertically integrated zooplankton (333 $\mu \mathrm{m}$ Bongo nets; Posgay \& Marak 1980) and mesozooplankton ( $80 \mu \mathrm{m}$ conical ring net) samples were collected in the upper $40 \mathrm{~m}$, which includes the permanent pycnocline. The zoo-

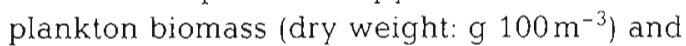
taxon specific abundance were determined from the Bongo samples and biomass only (dry weight: $g 100 \mathrm{~m}^{-3}$ ) from the conical net samples. For each Bongo tow, a sample from 1 of the 2 nets was preserved in a $4 \%$ formalin and 
seawater solution for the enumeration of decapod larvae. The sample from the second net was passed through $2 \mathrm{~mm}$ and $500 \mu \mathrm{m}$ sieves to obtain the 333 to $500 \mu \mathrm{m}$ and $500 \mu \mathrm{m}$ to $2 \mathrm{~mm}$ size fractions. The fractions were suspended and mixed in $2 \mathrm{l}$ of pure water and 2 subsamples $(25$ or $50 \mathrm{ml}$, depending on the density of organisms) were extracted. The first was preserved for taxon identification and enumeration, and the second was filtered on a $1.5 \mu \mathrm{m}$ pre-burned Whatman GF/F filter and frozen for biomass determination. Additional biomass estimates (no taxon identification) were made for 2 mesozooplankton size fractions (80 to 125 and 125 to $250 \mu \mathrm{m}$ ) using the above methodology. The 250 to $333 \mu \mathrm{m}$ size fraction was not included, as it was clear, by visually comparing the larger zooplankton from the conical $(80 \mu \mathrm{m})$ net with the smaller zooplankton from the Bongo $(333 \mu \mathrm{m})$ net from the same station, that the $80 \mu \mathrm{m}$ mesh net was not sampling the larger $(>250 \mu \mathrm{m})$ zooplankton efficiently. Nevertheless, the interval 250 to $333 \mu \mathrm{m}$ accounts for only $4 \%$ of the size range considered (i.e. $80 \mu \mathrm{m}$ to $2 \mathrm{~mm}$ ); therefore the size fractions retained ( 80 to $250 \mu \mathrm{m}, 333 \mu \mathrm{m}$ to $2 \mathrm{~mm}$ ) cover most of the reported feeding range for zoea I and II shrimp larvae (Stickney \& Perkins 1981). Dry weight was determined after each size fraction had been oven dried $\left(60^{\circ} \mathrm{C}\right)$ for $24 \mathrm{~h}$. Analysis of variance (ANOVA) was applied to the zooplankton biomass (square-root transformed) data to test for day and night, and sampling site effects on each size fraction. Significantly different means among sites were identified using the Student-Newman-Keuls (SNK) a posteriori test (Sokal \& Rohlf 1981).

The zooplankton community structure at each station was described by computing the 'relative dominance index' of each species or taxonomic category enumerated in the 333 to $500 \mu \mathrm{m}$ and the $500 \mu \mathrm{m}$ to $2 \mathrm{~mm}$ size fractions. The measure of relative dominance is based on the ratio of the proportion of taxon $i$ and the expected (mean) proportion of all other taxa in the sample (Kvålseth 1991):

$$
r_{i}=\frac{p_{i}}{E\left(P_{i}\right)}
$$

where $r_{j}$ is the 'relative dominance index' of taxon $i$, $p_{i}$ is the proportion of taxon $i$ in the sample, and $E\left(P_{1}\right)$ is the expected (weighted mean) proportion of the other taxa given by:

$$
E\left(P_{j}\right)=\frac{\sum_{j \neq i} p_{i}^{2}}{1-p_{i}}
$$

The lower limit of the index is 0 when $p_{i}=0$ and $r_{i}=1$ if all taxa are uniformly distributed in the sample (i.e. equal proportions); however, the index has no upper limit and $r_{i} \rightarrow \infty$ when $p_{1} \rightarrow 1$. Box plots of the $r_{i}$ index computed at each station for a site, and circuit, were constructed to visually compare the relative composition of the zooplankton community among sampling sites.

A minimum of 5 shrimp larvae were collected live from each zooplankton sample and immediately preserved in liquid nitrogen for fresh wet-weight determination and lipid analyses following the protocol used for individual shrimp larvae in Ouellet et al. (1992). The only modification was the addition of a third chromarods development [ $45 \mathrm{~min}$ in chloroform: methanol: water $(50: 30: 3, v: v: v)]$ for isolation and quantification of the polar lipid (phospholipids) classes (adapted from Murray 1985). Individual shrimp larval biomass as total organic carbon (org $\mathrm{C}$ zoea $^{-1}$ ) was estimated from total lipid data (i.e. summation of all lipid classes) using a relation for brachyuran larvae (Anger \& Harms 1990).

Total length (from the tip of the rostrum to the end of the telson) and carapace length (from the posterior end of the orbit to the posterior dorsal margin of the carapace) of the formaldehyde-preserved shrimp larvae were measured under a dissecting microscope.

\section{RESULTS}

\section{Water mass structure at the sites}

The surface mixed-layer temperature and salinity characteristics at each station illustrated the discrimination of the water masses among the sites for each sampling circuit, as differences among sites exceeded the differences within site (Fig. 2A, B). The surface water mass at Site $C$ was relatively more homogeneous and clearly colder and more saline (Fig. 2A, B). Advection of freshwater at Site A was apparent by the presence of less saline water during sampling circuit 2 (Fig. 2A, B). The analysis also indicated a gradient between the surface water masses of Sites A and B and the warming at Site $B$ relative to Site $A$

Major differences among sites were also observed in the vertical structure of the water column. Site A had a shallow $(<10 \mathrm{~m}$ ) mixed layer above an extended (to $50 \mathrm{~m}$ ) pycnocline (Fig. 3A). Distinct subsurface maxima in suspended particles, as shown by beam attenuation, were observed within the pycnocline and above the cold intermediate layer (Fig. 3A). Site B also had a shallow $(<10 \mathrm{~m})$ mixed layer, but showed stronger temperature and density gradients relative to Site $A$ and a less extensive cold intermediate layer (Fig. 3B). Correspondingly, suspended particle concentrations were much lower than at Site $\mathrm{A}$, limited to the upper $20 \mathrm{~m}$, and no distinct subsurface maxima were observed at the pycnocline. In contrast, the shallower Site $C$ had the deepest mixed layer $(\sim 20 \mathrm{~m})$ and the weakest thermocline and pycnocline (Fig. 3C). Suspended particle 

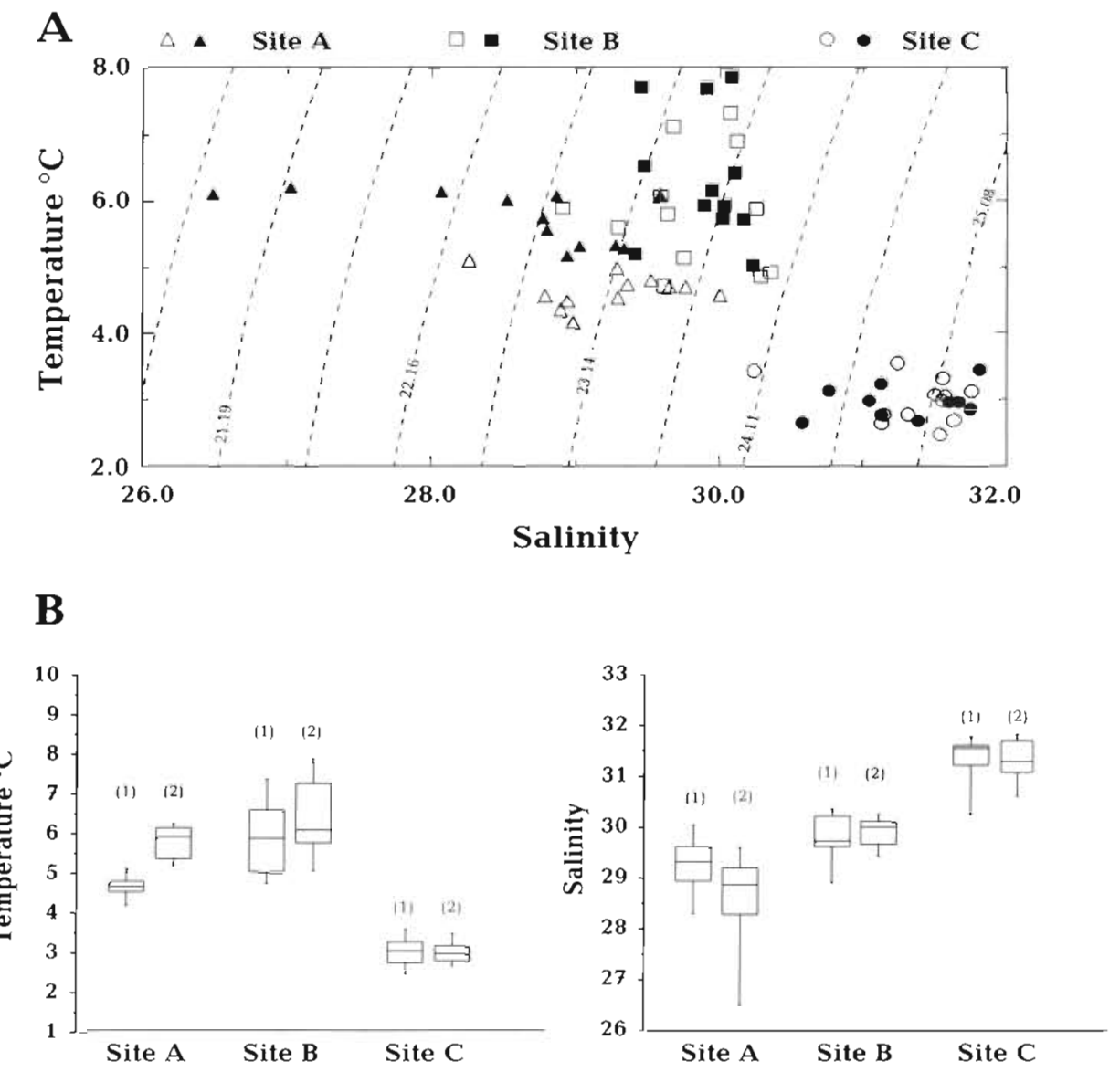

Fig. 2. (A) Combined temperature and salinity diagram from the averaged mixed layer at each station (open symbols: circuit 1 ; closed symbols: circuit 2). Constant density $\left(\sigma_{t}\right)$ lines are also indicated. (B) Box plots summarizing the mixed-layer characteristics (temperature and salinity) at the sampling sites for each sampling circuit. Each box presents the median (horizontal line), the upper and lower quartiles (upper and lower bounds of the rectangle\}, and the range (vertical line) in the data

concentrations at Site $C$ were much lower than at Site B and more uniformly distributed with depth.

\section{Abundance, growth, and size variability of shrimp larvae}

Average (total) concentrations (number $100 \mathrm{~m}^{-3}$ ) of larval shrimp among circuits at Sites $\mathrm{A}$ and $\mathrm{C}$ were 10-fold higher than concentrations at Site B (Table 1). Co-occurrence of different developmental stages was noted at all sites, but zoea I larvae were more abundant at Site $A$ whereas zoeae II dominated at Sites B and $C$ (Table 1). The zoeae II were significantly larger in size (wet weight) and length (carapace and total) at Site $C$ than at Sites B and A (Table 2). The zoea II lar-

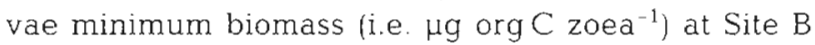
ranged from 39.6 to $45 \mu \mathrm{g}$ (average: $42.3 \mu \mathrm{g}$ ) relative to minimum biomass ranging from 64.2 to $80.5 \mu \mathrm{g}$ and 53.9 to $59.4 \mu \mathrm{g}$ at Sites A and C respectively (Table 3). Although the means of all zoeae II at each site were not statistically different, the differences in zoea II larvae minimum size among sites are interpreted as the consequences of differential larval growth performance, i.e. the net gain in body size at the first moult.

\section{Shrimp larvae lipid composition and TAG content}

Overall, the phospholipids (phosphatidylcholine and phosphatidylethanolamine) accounted for more than $80 \%$ of all lipids in both zoea I and zoea II shrimp larvae (Fig. 4). Among the neutral lipids, the diacylglycerols $(\sim 10 \%)$ and the free sterols $(\sim 6 \%)$ were more

Table 1. Pandalus borealis. Mean ( $\pm \mathrm{SD}$ ) concentration (num ber $100 \mathrm{~m}^{-3}$ ) of shrimp larvae at the sampling sites during both circuits. $N=12$ stations at all sites except for circuit 2 at Site $C$ where $N=10$

\begin{tabular}{|ccccc|}
\hline Circuit & Total & Zoea I & Zoea II & Zoea III \\
\hline Site A & & & & \\
1 & $15.2 \pm 15.1$ & $10.0 \pm 9.7$ & $5.1 \pm 7.5$ & $0.1 \pm 0.2$ \\
2 & $32.2 \pm 26.1$ & $21.6 \pm 17.8$ & $10.7 \pm 9.0$ & 0 \\
Site B & & & & \\
1 & $4.6 \pm 4.8$ & $0.5 \pm 1.8$ & $4.1 \pm 3.5$ & 0 \\
2 & $3.2 \pm 2.6$ & $0.6 \pm 0.8$ & $2.7 \pm 2.4$ & 0 \\
Site C & & & & \\
1 & $27.4 \pm 34.0$ & $0.4 \pm 0.8$ & $25.8 \pm 32.5$ & $1.2 \pm 1.5$ \\
2 & $30.2 \pm 21.3$ & $0.6 \pm 1.1$ & $28.3 \pm 20.2$ & $1.3 \pm 1.4$ \\
\hline
\end{tabular}


Fig. 3. Temperature (T), density $\left(\sigma_{t}\right)$, and beam attenuation $\left(a, \mathrm{~m}^{-1}\right)$ profiles at each sampling site (solid lines: circuit 1 dashed lines: circuit 2). For the extremes for each grid and circuit are presented to illustrate the degree of variability at each site $(A, B$, and $C)$ clarity, only the median and

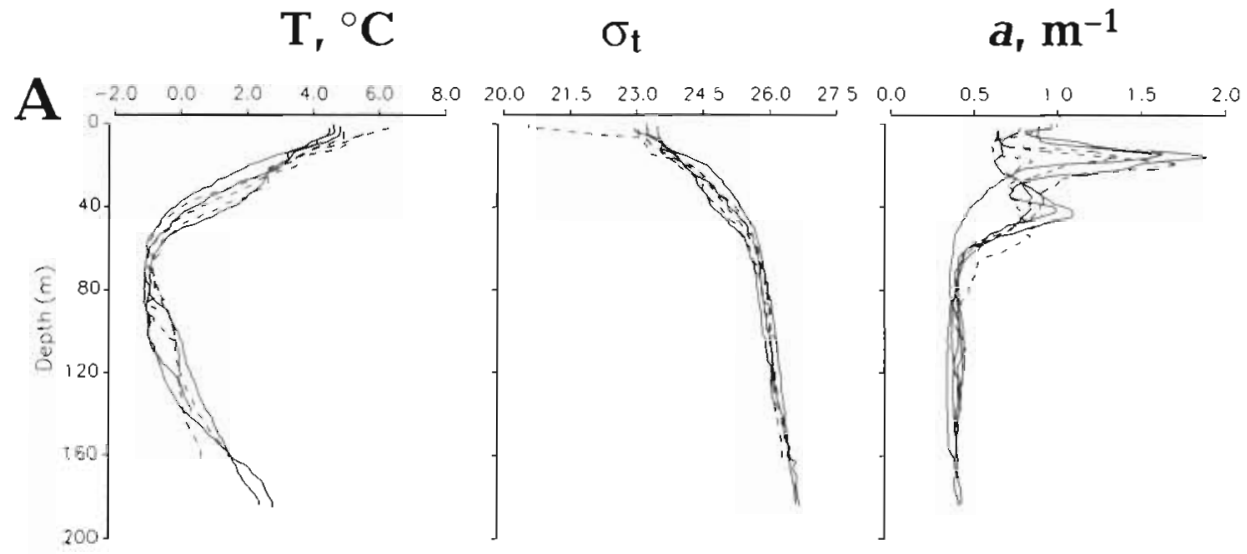

B
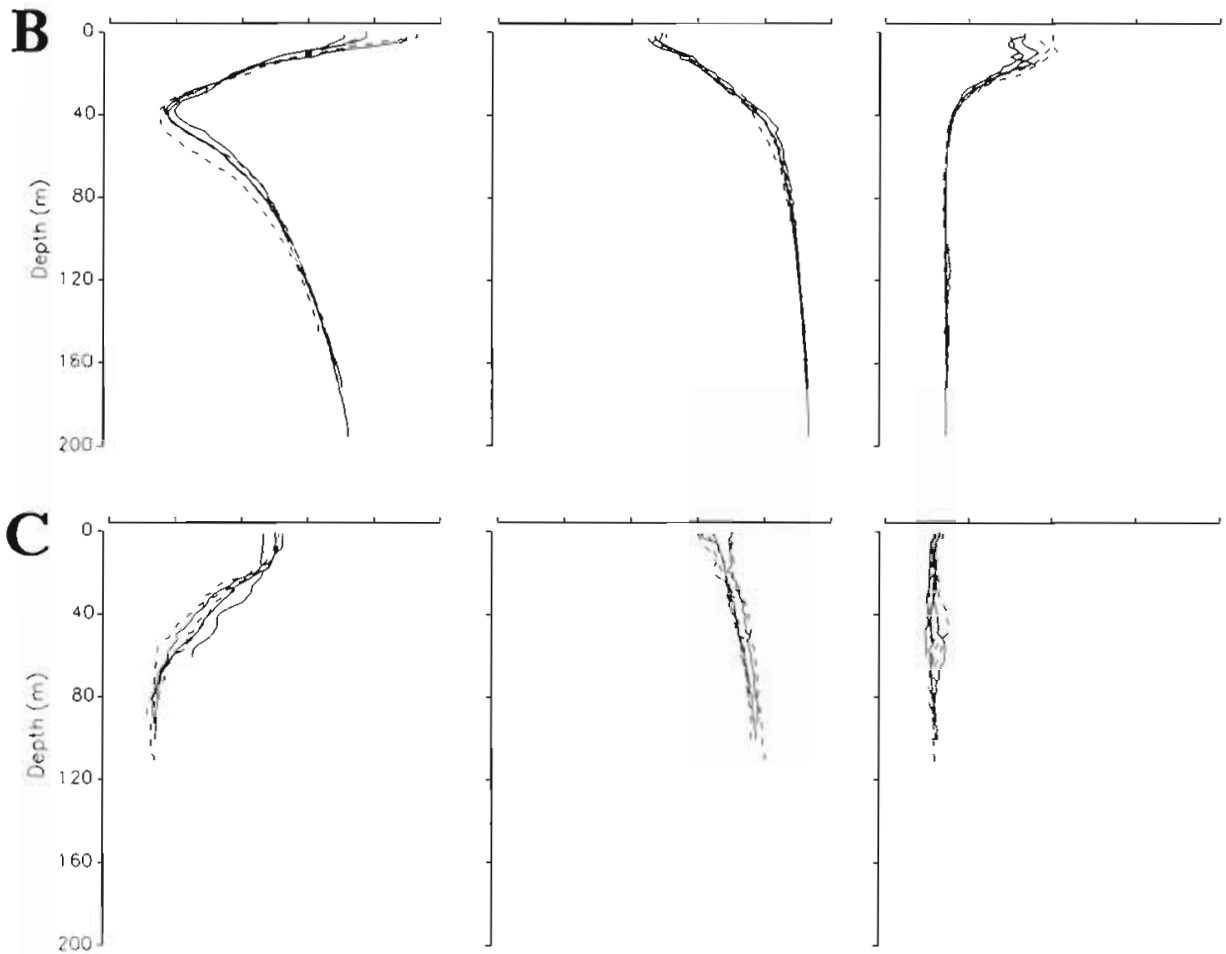

\section{Zooplankton biomass and community structure}

sterol or fatty-acid esters were recorded (Fig. 4). Frequency distributions of the standardized individual TAG content (i.e. the TAG ww ${ }^{-1}$ condition index) showed higher variability, i.e. greater range, for the zoeae I at Site A relative to Sites B and C, where zoeae II dominated (Fig. 5). Very few zoeae II were preserved for the biochemical analysis at Site A (circuit 1: $\mathrm{N}=4$, mean $\mathrm{TAG} w \mathrm{w}^{-1}=0.51 \pm 0.29$, range $=$ 0 to 0.66 ; circuit $2: \mathrm{N}=9$, mean $\mathrm{TAG} w w^{-1}=0.76 \pm$ 0.79 , range $=0.18$ to 2.87 ) , nevertheless, higher proportions of zoea II larvae in poor condition (TAG ww ${ }^{-1}$ $\leq 0.2$ ) were observed at Site $B$ relative to Sites $C$ and A (zoeae I), especially during sampling circuit 1 at Site B (Fig. 5).
From the Bongo samples, the larger $(500 \mu \mathrm{m}$ to 2 mm) zooplankton biomass was much lower at Site $C$ relative to Sites A and B [ANOVA (SNK), $p<0.05$; circuit 1 and 2 night samples] whereas zooplankton biomass in the smaller (333 to $500 \mu \mathrm{m}$ ) size fraction was significantly higher at Site A relative to Sites B and C [ANOVA (SNK), $\mathrm{p}<0.05$; circuit 1 night samples and circuit 2 day samples] (Fig. 6). The mesozooplankton biomass in the 125 to $250 \mu \mathrm{m}$ size fraction from the conical net was significantly lower at Site B relative to Sites $A$ and C [ANOVA (SNK), p < 0.05; circuit 1 day samples] and significantly higher at Site $A$ relative to Sites B and C [ANOVA (SNK), $p<0.05$; circuit 1 night 
samples] (Fig. 6). For the smaller size fraction ( 80 to $125 \mu \mathrm{m}$ ), biomass was significantly lower at Site B relative to Site A [ANOVA (SNK), $p<0.05$; circuit 1 day and night samples] (Fig. 6).

Overall, the larger (500 $\mu \mathrm{m}$ to $2 \mathrm{~mm}$ ) zooplankton community structure was similar at all sampling sites and the calanoid copepods (Calanus finmarchicus, C. hyperboreus late copepodites or adults) dominated the zooplankton community (Fig. 7). Interestingly, C. finmarchicus was more abundant than $C$. hyperboreus at Sites $\mathrm{A}$ and $\mathrm{B}$, i.e. the northwest sector, whereas C. hyperboreus was the dominant calanoid copepod at Site C. Although the concentrations of C. finmarchicus were similar between Sites $A$ and $B$, and both concentrations were comparable to $C$. hyperboreus copepodite stage concentrations at Site $C$, the younger (smaller) copepodite stages (C. finmarchicus or C. hyper-
Table 2. Pandalus borealis. Mean $( \pm \mathrm{SD}$ ) total length, carapace length (formaldehyde-preserved specimens), and wet weight (frozen specimens) for shrimp larval stages at each sampling site during both circuits (C). "Statistically significant differences [ANOVA (SNK), $p<0.05$ ] among sampling sites for each circuit

\begin{tabular}{|crrccrc|}
\hline Circuit & Zoea & $N$ & $\begin{array}{c}\text { Total length } \\
(\mathrm{mm})\end{array}$ & $\begin{array}{c}\text { Carapace length } \\
(\mathrm{mm})\end{array}$ & $\mathrm{N}$ & $\begin{array}{c}\text { Wet weight } \\
(\mathrm{mg})\end{array}$ \\
\hline Site A & & & & & & \\
1 & I & 54 & $6.29 \pm 0.26$ & $1.25 \pm 0.10$ & 24 & $1.84 \pm 0.37$ \\
& II & 23 & $7.91 \pm 0.50$ & $1.63 \pm 0.15$ & 4 & $2.99 \pm 0.60$ \\
2 & I & 54 & $6.39 \pm 0.40$ & $1.24 \pm 0.11$ & 34 & $2.05 \pm 0.39$ \\
& II & 35 & $7.92 \pm 0.51$ & $1.67 \pm 0.14$ & 9 & $3.67 \pm 0.53$ \\
Site B & & & & & & \\
1 & I & 2 & $6.18 \pm 0.41$ & $1.16 \pm 0.00$ & & \\
& II & 5 & $8.25 \pm 0.60$ & $1.71 \pm 0.25$ & 22 & $3.44 \pm 0.76$ \\
2 & I & 2 & $6.55 \pm 0.12$ & $1.33 \pm 0.11$ & & \\
& II & 11 & $7.94 \pm 0.45$ & $1.76 \pm 0.16$ & 16 & $3.42 \pm 0.60$ \\
Site C & & & & & & \\
1 & II & 108 & $8.65 \pm 0.48^{\circ}$ & $1.83 \pm 0.16^{\circ}$ & 62 & $4.09 \pm 0.57$ \\
& III & 9 & $10.76 \pm 0.37$ & $2.39 \pm 0.16$ & & \\
2 & I & 2 & $6.39 \pm 0.01$ & $1.33 \pm 0.00$ & & \\
& II & 102 & $8.39 \pm 0.42$ & $1.81 \pm 0.15^{\circ}$ & 62 & $4.26 \pm 0.72 \cdot$ \\
& III & 10 & $10.21 \pm 0.23$ & $2.38 \pm 0.11$ & & \\
\hline
\end{tabular}
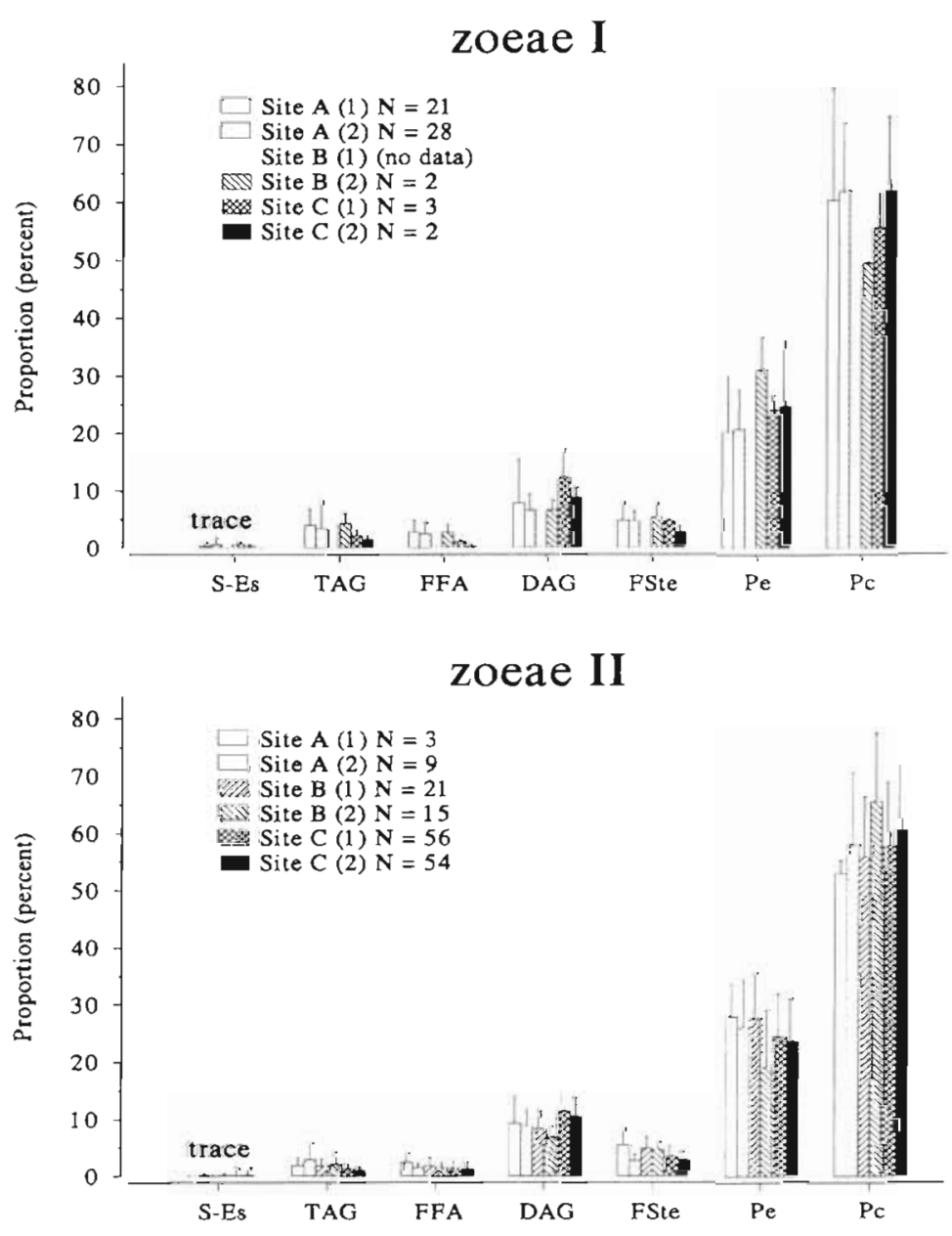

boreus) were more abundant at Site $A$ than at Sites B and C (Table 4).

The smaller (333 to $500 \mu \mathrm{m}$ ) zooplankton were relatively more diversified, with more taxa showing a high relative dominance index within each sampling site (Fig. 7). Larvaceans were the dominant taxonomic group at all sites, but collectively calanoid copepod eggs, nauplii, and small copepodite stages were more important, especially at Site A (Fig. 7. Table 4). The 333 to $500 \mu \mathrm{m}$ zooplankton at Site $C$ was different, as radiolarians (protozoan) and euphausiid larval stages dominated relative to the calanoid developmental stages (Fig. 7). However, calanoid developmental stages (eggs, nauplii, and copepodites) together were again numerically more abundant at Site Crelative to Site B (Table 4 ).

Fig. 4. Pandalus borealis. Lipid composttion of shrimp larvae at each sampling site and circuit. S-Es: sterols-ester; TAG: triacylglycerols; FFA: free fatty acids; DAG: diacylglycerols; FSte: free sterols; $\mathrm{Pe}$ : phosphatidylethanolamine; Pc: phosphatidylcholine. Total lipid composition was possible for only a single zoea I larva at Site B (circuit 1) so the values are not presented on the plot 
Table 3. Pandalus borealis. Biomass of shrmmp larvae expressed as organic carbon per zoea ( $\mu \mathrm{g}$ org $\mathrm{C}$ zoea ${ }^{-1}$ ) at each sampling site during both circuits

\begin{tabular}{|c|c|c|c|c|c|c|c|}
\hline \multirow[t]{2}{*}{ Zoea } & & \multicolumn{2}{|c|}{ Site A } & \multicolumn{2}{|c|}{ Site B } & \multicolumn{2}{|c|}{ Site $C$} \\
\hline & & (1) & (2) & (1) & (2) & (1) & (2) \\
\hline \multirow[t]{4}{*}{ I } & $N$ & 22 & 27 & & & & \\
\hline & Minimum & 15.2 & 24.1 & & & & \\
\hline & Maximum & 201.2 & 198.3 & & & & \\
\hline & Mean $\pm \mathrm{SD}$ & $85.8 \pm 59.2$ & $86.3 \pm 40.1$ & & & & \\
\hline \multirow[t]{4}{*}{ II } & $\mathrm{N}$ & 4 & 8 & 22 & 15 & 49 & 50 \\
\hline & Minimum & 64.2 & 80.5 & 45.0 & 39.6 & 53.9 & 59.4 \\
\hline & Maximum & 158.8 & 226.2 & 187.5 & 207.5 & 513.1 & 552.2 \\
\hline & Mean \pm SD & $106.1 \pm 42.8$ & $144.5 \pm 51.9$ & $111.6 \pm 40.9$ & $130.8 \pm 53.7$ & $181.3 \pm 69.3$ & $195.9 \pm 91.1$ \\
\hline
\end{tabular}
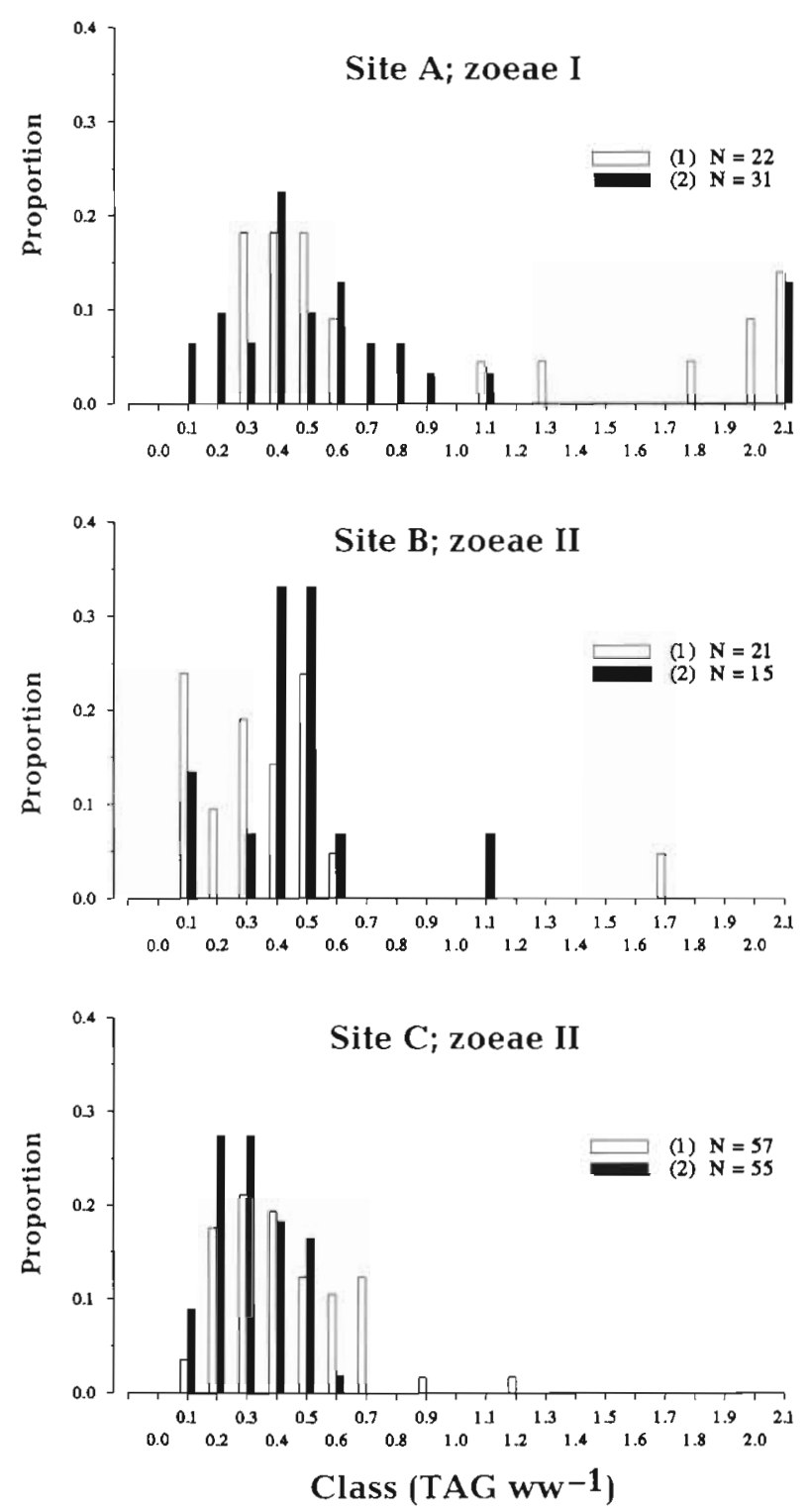

Fig. 5. Pandalus borealis. Frequency distributions of the individual TAG $w^{-1}$ condition index for shrimp larval cohorts at each site

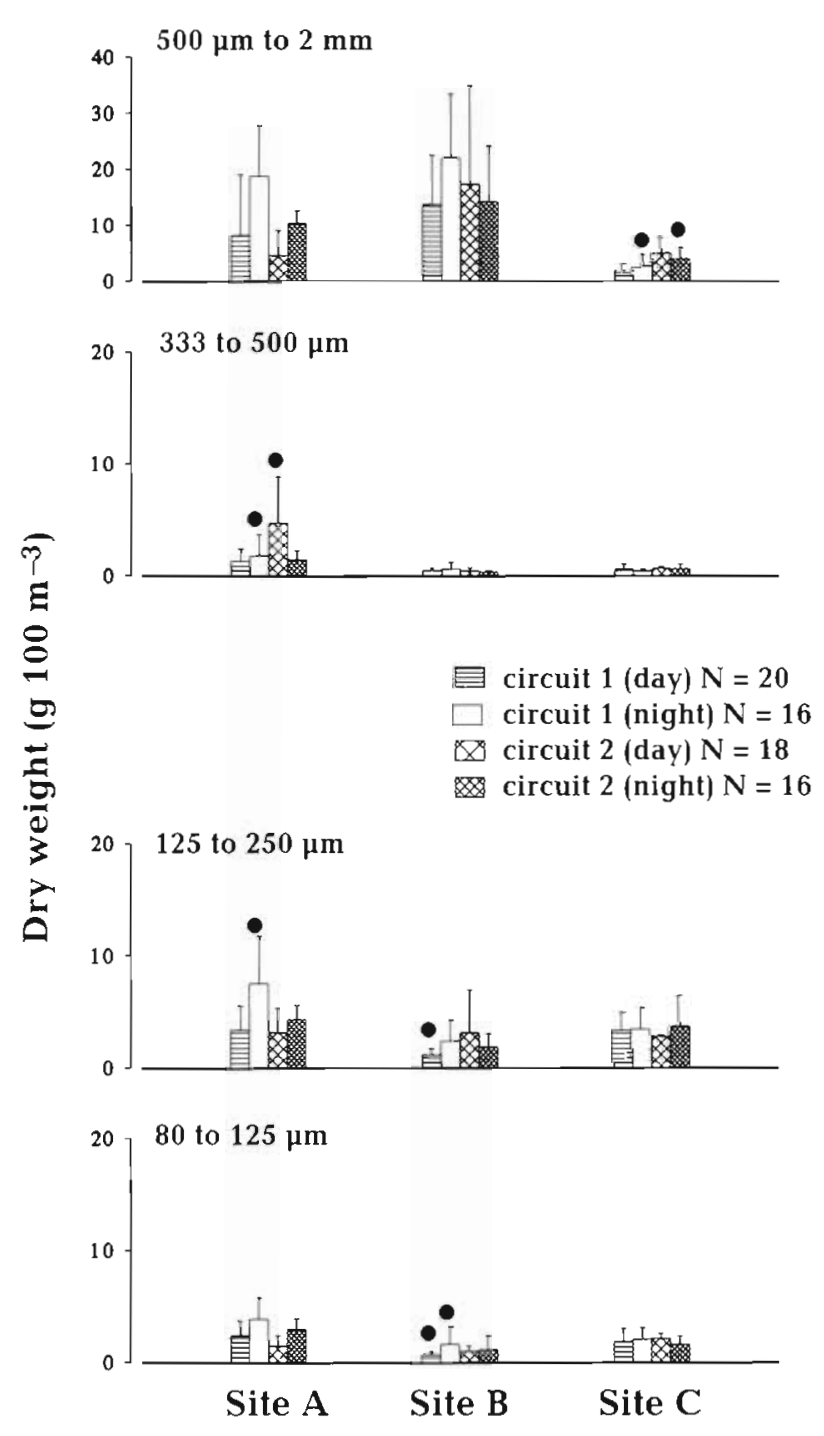

Fig. 6. Comparison of the mean (+1 SD) zooplankton biomass in 4 size fractions among sampling sites for day and night sampling periods. ( ) Significant differences [ANOVA (SNK), $p<0.05]$ among sampling sites 

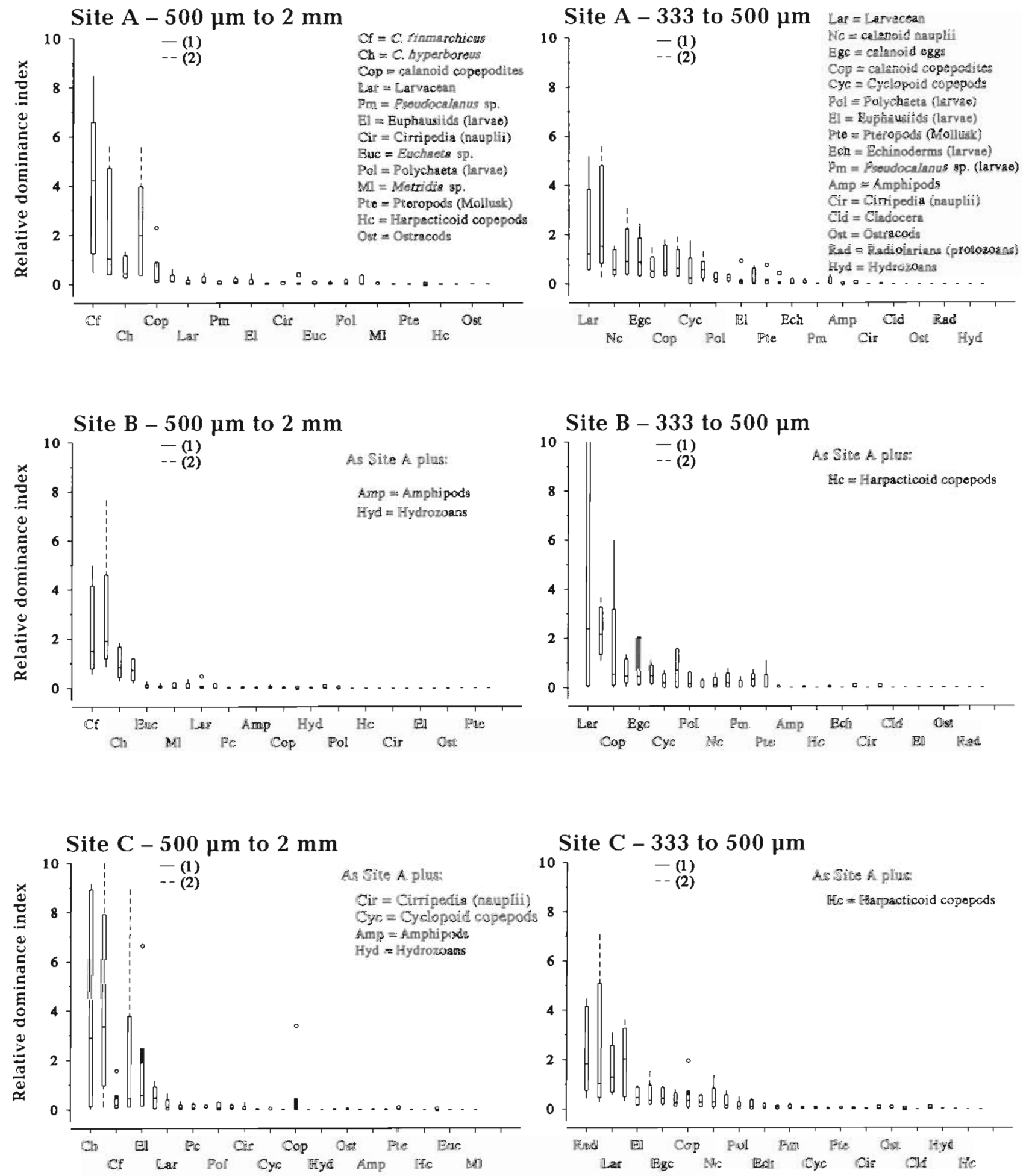

Fig. 7. Box plots summarizing the zooplankton community structures. Each plot presents the median (horizontal line), the upper and lower quartiles (upper and lower bounds of the rectangle), and the range (vertical line) of the relative dominance indexes computed at each site and sampling circuit, for 2 size fractions. On the $x$-axis, the taxa are ordered from the most dominant (i.e. highest relative dominance index) to the least (i.e. lowest relative dominance index) according to the results for the first sampling circuit at each site 
Table 4. Mean $( \pm \mathrm{SD})$ calanoid copepod developmental stage concentration (number $\mathrm{m}^{-3}$ ) among sampling sites

\begin{tabular}{|c|c|c|c|c|}
\hline Taxon & Circuit & Site A & Site B & Site C \\
\hline \multicolumn{5}{|l|}{$500 \mu \mathrm{m}$ to $2 \mathrm{~mm}$} \\
\hline Calanus finmarchicus & $\begin{array}{l}1 \\
2\end{array}$ & $\begin{array}{c}153.4 \pm 176.4 \\
97.2 \pm 80.4\end{array}$ & $\begin{array}{l}115.8 \pm 73.6 \\
148.6 \pm 80.2\end{array}$ & $\begin{array}{l}26.9 \pm 30.8 \\
90.1 \pm 66.4\end{array}$ \\
\hline Calanus hyperboreus & $\begin{array}{l}1 \\
2\end{array}$ & $\begin{array}{l}59.1 \pm 27.7 \\
69.8 \pm 19.1\end{array}$ & $\begin{array}{r}98.9 \pm 77.3 \\
101.9 \pm 97.2\end{array}$ & $\begin{array}{l}112.7 \pm 109.9 \\
236.9 \pm 125.1\end{array}$ \\
\hline Copepodite stages $^{a}$ & $\begin{array}{l}1 \\
2\end{array}$ & $\begin{array}{l}26.5 \pm 21.3 \\
17.1 \pm 17.4\end{array}$ & $\begin{array}{l}0.9 \pm 1.8 \\
0.2 \pm 0.8\end{array}$ & $\begin{array}{c}5.1 \pm 17.6 \\
-b\end{array}$ \\
\hline \multicolumn{5}{|l|}{333 to $500 \mu \mathrm{m}$} \\
\hline copepodites & $\begin{array}{l}1 \\
2\end{array}$ & $\begin{array}{l}76.1 \pm 76.3 \\
93.2 \pm 42.3\end{array}$ & $\begin{array}{l}2.7 \pm 2.3 \\
0.9 \pm 0.5\end{array}$ & $\begin{array}{r}106.8 \pm 75.8 \\
74.0 \pm 39.3\end{array}$ \\
\hline $\begin{array}{l}{ }^{\circ} C \text {. finmarchicus and } C \\
{ }^{\circ} \text { Included with } C \text {, hype }\end{array}$ & $\begin{array}{l}\text { hyperb } \\
\text { rboreus }\end{array}$ & $\begin{array}{l}\text { reus } \\
\text { bove }\end{array}$ & & \\
\hline
\end{tabular}

\section{DISCUSSION}

Despite their relative proximity, sampling Sites A and $B$ were located in independent hydrographic regions separated by a near surface density front delineating the westward, density-driven, coastal current and the anticyclonic gyre in the northwest sector of the Gulf (Koutitonsky \& Bugden 1991) (Fig. 8). The narrow passage between the Quebec coast and the west end of Anticosti Island is a region where cold surface waters, originating from upwelling along the nor th shore to the east, and strong tidal current, mixing the cold intermediate layer with the surface layer, contribute to the persistence of a cold and relatively well mixed water column (Koutitonsky \& Bugden 1991). The characteristic water column observed at Site C reflects the eastward advection of this water mass along the north side of Anticosti Island. Moreover, the frontal region created by tidal mixing over the shallows contribute to the isolation of the northwest sector from the north Anticosti sector (see de Lafontaine et al. 1991). Differences in the zooplankton biomasses and community structures among sectors and sites, e.g. the very low abundance of calanoid developmental stages at Site $B$ relative to Site $A$, and the dominance of Calanus hyperboreus and radiolarians at Site $\mathrm{C}$, support the conclusion that the 3 sampling sites represent distinct environments for the shrimp larvae.

Although the zoeae II at Sites A and B both originated from the northwest sector spawning stock, the difference in body length and size (org C) increment at the first moult indicated the independent development of the 2 larval groups. Comparison of body size minima, for a given moult stage, should be an adequate estimate of larval size increment at the moult since variability in growth, as the larvae progress through the stage, can render comparison of the mean values for the entire stage much less accurate. Calanoid copepod developmental stages concentrations were similar among Sites A and C, nevertheless, the bigger zoea II larvae at Site $C$ relative to Site A could also be the result of enhanced growth at Site $C$ (maybe caused by differences in quality or caloric content of the food). Shrimp larval size at age or moult stage was found to be independent of rearing temperatures (Wienberg 1982), suggesting that the lower mean water temperature at Site $C$ cannot explain the difference in larval size. Alternatively, lower incubation temperatures (i.e. during egg development) were found to be responsible for bigger larvae at hatching (Nunes 1984). However, mean deep (100 to $200 \mathrm{~m}$ ) water temperatures, where egg-carrying female shrimp are found, are relatively uniform (a difference of $\pm 1^{\circ} \mathrm{C}$ in 1994) among the northwest and north Anticosti sectors (D. Gilbert, Institut Maurice-Lamontagne, pers. comm.), and the homogeneity of zoea I shrimp larval cohorts among the sec-

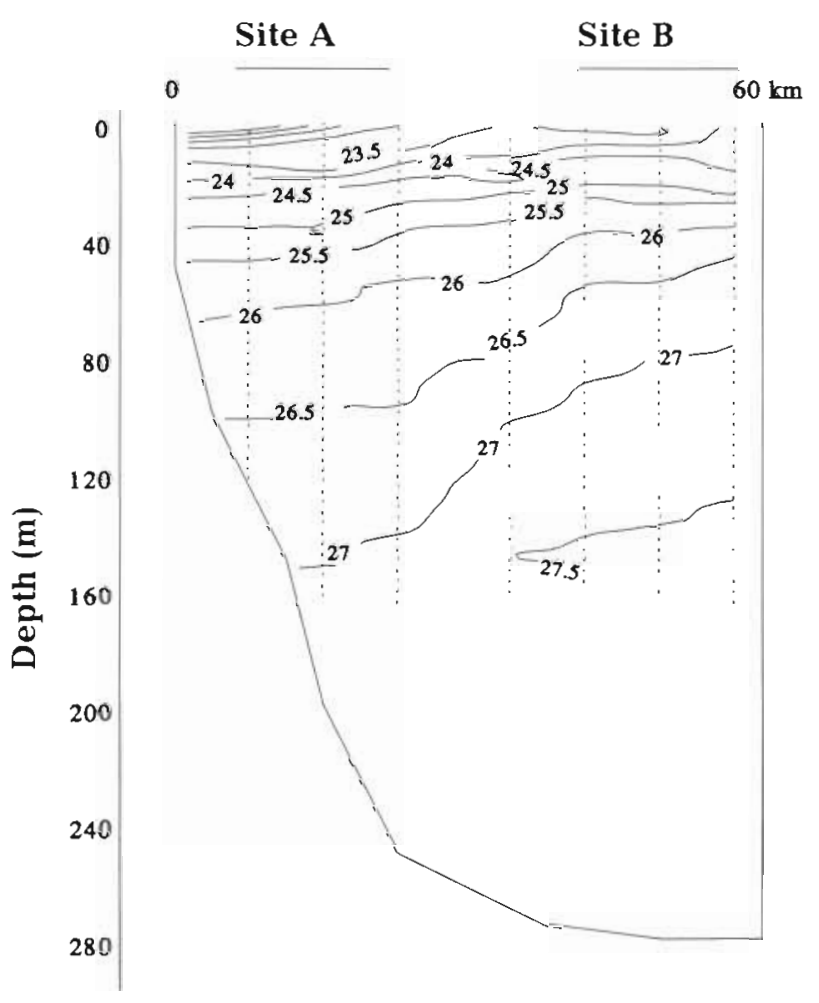

Fig. 8. Isopycnal $\left(\sigma_{1}\right)$ distribution at a cross-section from Quebec's north shore to the northwest anticyclonic gyre (left to right), cutting through sampling Sites A and B (see Fig. 1) 
tors of the northern Gulf has been shown in a previous investigation (Ouellet et al. 1990). Therefore, it is a reasonable assumption that the observed differences in the zoeae II size is the result of differential growth performance among sites and the 3 sampling sites were supporting distinct larval shrimp cohorts. It is also important to understand that larval size alone is not indicative of the survival potential of the larvae. Moreover, the TAG index used to assess larval condition is weighted by the larvae body size

\section{Lipid composition, TAG content, and survival expectations of shrimp larvae}

The structural lipid fraction (i.e. phospholipids) accounted for most of the total lipid in the shrimp larvae. Although previous studies have shown that the TAG could account for 20 to $40 \%$ of the total lipid in age 1+ Pandalus borealis shrimp (Hopkins et al. 1993), studies on prawn Penaeus spp. have revealed that most lipids are associated with cell membranes and that relatively few reserve lipids are accumulated during moulting cycles (Chandumpai et al. 1991, Dall et al. 1993). More surprising was the high content of the diacylglycerols (DAG) in the shrimp zoeal stages. DAG are usually present in very low quantities in live animal tissues, thus the relatively high proportion of DAG in the samples could reflect lipid degradation during storage. However, the hydrolysis of TAG produces proportional quantities of DAG and free fatty acids. Therefore, the low proportion of FFA (Fig. 4), together with the absence of a significant relationship between the TAG and DAG contents (data not shown), supports the conclusion that the high DAG quantities reflect metabolic activity associated with biosynthesis of cell membranes or assimilation of dietary lipids. A marked increase in the 1,3-DAG was observed in the digestive gland of well-fed prawn (Chandumpai et al. 1991). In addition, experiments with ${ }^{14} \mathrm{C}$-labelled dietary lipids in the prawn Penaeus esculentus revealed that most of the assimilated fatty acids were incorporated into the phospholipid fraction (Dall et al. 1993). Indeed 1,2DAG is an important precursor in the biosynthesis pathway of both the phospholipids and the TAG (Vance \& Vance 1985). Moreover, in situations where the availability of fatty acid is low (as the low proportion of FFA in the samples would suggest; Fig. 4), the major flux from DAG is directed to phospholipid synthesis (Vance \& Vance 1985). Consequently, the TAG data can be considered as a conservative index of the amount of short-term energy reserves and of the condition of the shrimp larvae at the sampling sites.

The use of a relatively simple index based on the TAG content of shrimp larvae was proposed to assess the effects of feeding conditions on survival in the laboratory (Ouellet et al. 1992). To apply the method in the field it is necessary to obtain representative samples of larval cohorts for the entire moult cycle. This requirement stems from the fact that the method uses the frequency distribution of the individual condition indices to assess the overall condition of larval cohorts. Brief but synchronous larval emergence periods characterize shrimp reproduction in the northern Gulf of St. Lawrence, and the northwest and the north centre sampling sites correspond to the principal emergence areas for these stocks (Ouellet et al. 1990). The variation in the TAG Ww ${ }^{-1}$ frequency distributions and the wide range in zoeal biomass (total organic carbon) observed among the sites support the conclusion that the samples were representative of shrimp larvae at all phases of the moult cycle. A wide range of values is expected when sampling larvae at various phases in the moult cycle due to the pattern of accumulation and depletion in organic carbon (i.e. lipid reserves), as documented for Majidae (crabs) and Pandalidae (shrimp) larvae (Anger et al. 1989, Ouellet et al. 1992, Lovrich \& Ouellet 1994). Moreover, despite the fact that TAG represented less than $5 \%$ of all lipids, the frequency distributions of the TAG $w w^{-1}$ index from the sampling sites were similar to the patterns observed for the Artemia-fed larvae in the laboratory (Ouellet et al. 1992, their Fig. 6). Therefore, the differences observed in the TAG condition of shrimp larvae among the sampling sites reflect trophically induced variability in larval shrimp in the different environments and can be associated with different survival expectations at the moult.

The survival data from Ouellet et al. (1992) were reanalyzed to establish the relationship between shrimp larvae cumulative survival through the first 2 moults and the proportion of larvae in poor TAG condition during the zoea I (Site A) or zoea II (Sites B and C) stages (Fig. 9). When the proportions of shrimp larvae in poor TAG condition at the sampling sites are transposed into survival expectations using the relationship, few differences are observed among sites, and survival is expected to be high at all sites, but noticeably lower survival is expected for zoeae II at Site $B$ relative to Sites A (zoeae I) and C (Fig. 9). The relatively high survival expectations at all sites can in part be explained by the late date of sampling, i.e. by the dominance of zoea II larvae at the Sites C and B. In the laboratory, higher mortalities were recorded at the first moult with increasing survival at moult for the older stages (Ouellet et al. 1992). However, high survival expectations were also estimated for the zoea I larvae at Site A and, overall, the results would suggest that most shrimp larvae were unlikely to suffer from limited food resources in the sectors of the Gulf in 1990. These survival estimates could also be judged too simple to be realistic, 
e.g. they do not include other factors such as predation. Nevertheless, the approach illustrates the potential of developing and applying a laboratory-derived (simple) condition index to diagnose the survival potential of shrimp larval cohorts from the field.

\section{Shrimp larvae lipid condition and ecological characteristics of the sites}

Species-specific responses to hydrographic (vertical stratification, temperature) and hydrodynamic (advection, mixing of water masses) influences determine the development of different zooplankton communities within and among the sectors of the Gulf of St. Lawrence (de Lafontaine et al. 1991). The conditions at Site A (i.e. a dynamic thermocline/pycnocline region) were favourable to calanoid production as inferred from the high concentration of copepod developmental stages. Enhanced copepod production has been documented in areas associated with high chlorophyll a concentrations (Richardson 1985, Runge 1985), and potentially by high concentrations of microzooplankton (Kleppel et al. 1991). Enhanced vertical nutrient flux can stimulate and maintain phytoplankton production and generate an accumulation of chl a biomass at the pycnocline/nitracline depth (Cullen et al. 1983). As the beam attenuation coefficient has been shown to be indicative of chl a biomass in a variety of marine environments (Lieberman et al. 1984, Vandevelde et al. 1988), the maxima observed in the water column at Site $A$ can be interpreted as a subsurface chl a maxima. However, the maxima can also represent an accumulation of detrital material (following a bloom) at the density discontinuity and not necessarily enhanced production, particularly at the greater depth.
Lower zooplankton biomasses in the smaller size fractions and the much lower concentrations of copepod eggs, nauplii, and small copepodites observed at Site B reflect limited local production as well as reduced horizontal exchanges between the adjacent sampling sites. The strong density stratification at Site B can prevent the transport of nutrients to the surface layer and hence limit primary production in that area of the northern Gulf (Sévigny et al. 1979). Beam attenuation profiles also suggested phytoplankton concentration in the upper layer and limited accumulation of chl a biomass at the pycnocline, a situation expected when production is not driven by cross-pycnocline transport of nutrients (Cullen et al. 1983).

The dominance of Calanus finmarchicus at Sites A and B is typical of the northwestern Gulf of St. Lawrence (de Lafontaine et al. 1991). The shift in dominant calanoid copepod species between the northwest and north Anticosti sectors reflects the different oceanographic influences of the 2 sectors. The intrusion of cold water from the Labrador Current through the Strait of Belle Isle in the northeast sector of the Gulf may explain the origin and relative abundance of the copepod species $C$. hyperboreus in the zooplankton community north of Anticosti Island. Nevertheless, the abundance of copepod eggs, nauplii, and small copepodites relative to more advanced (larger) copepodite stages or the adults, and the relative importance of euphausiid larval stages, would suggest enhanced secondary production. At Site $C$, however, beam attenuation values were much lower than at Sites $\mathrm{A}$ and $\mathrm{B}$. Therefore, advection of larval stages produced at the frontal region (northwest end of Anticosti Island) or along Quebec's north shore is more likely responsible for the zooplankton community found at the site.
Fig. 9. Pandalus borealis. Relationship between cumulative shrimp larvae survival through the first 2 moults and the proportion of zoeae in low lipid (TAG) condition (from Ouellet et al. 1992): $(\bullet$, zoeae I reared on Artemia nauplii high-density diets, HD-A and $\mathrm{HD}-\mathrm{B}$ respectively; ( $₫$ ) zoeae I reared on Artemia nauplii low-density (LD-A) diet: $(\bullet)$ zoeae 1 reared on Isochrysis spp. cells: $(O, D)$ zoeae II on $\mathrm{HD}-\mathrm{A}$ and $\mathrm{HD}$ - $\mathrm{B}$ respectively; $(\Delta)$ zoeae II on LD-A. The prediction equation was used to locate the shrimp larval cohorts from the field on the relationship

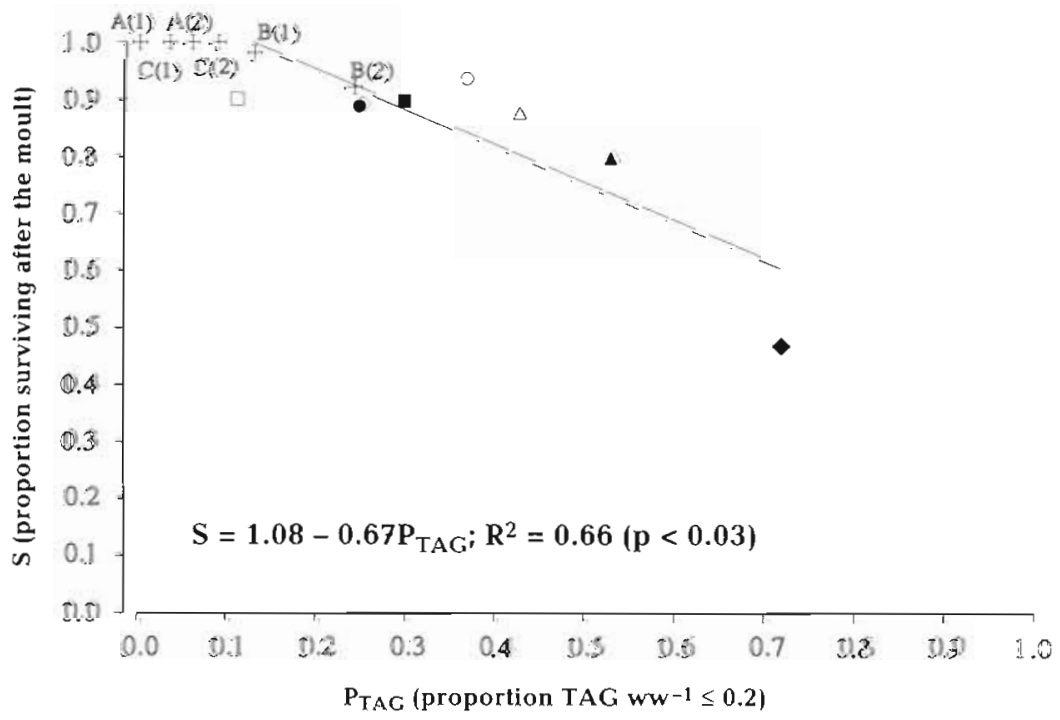


In summary, Sites A and C presented high copepod developmental stage concentrations (i.e. secondary production), and relatively more diversified zooplankton communities, that probably developed following enhanced and sustained primary production in areas where hydrographic conditions were favorable to nutrient transport and mixing in the upper layer of the water column.

In their study on the natural diet of zoea I and II shrimp larvae, Stickney \& Perkins (1981) listed diatom fragments as the most abundant item, followed by crustacean, polychaete, and unidentified invertebrate fragments. These results seem to suggest that young shrimp larvae are omnivorous, opportunistic feeders much like adult shrimp (Shumway et al. 1985). In addition, laboratory experiments have shown that zoea I shrimp larvae captured copepod nauplii and copepodite stages at relatively high $\left(>20\right.$ items $\left.l^{-1}\right)$ concentrations (Paul et al. 1979). The concentrations of all calanoid stages at any sampling site were lower than the laboratory value, likely due to the integrated tows that tend to yield low values of the highly concentrated micro-patches of zooplankton in the water column. However, the larger larval size and the higher proportion of zoeae in good TAG condition at Sites C and A respectively were coincident with higher concentrations of copepod stages at these sites relative to Site B, suggesting a relationship between shrimp larval growth, condition, and survival potential and secondary production in the water column. Moreover, more zooplankton biomass at Sites $\mathrm{A}$ and $\mathrm{C}$ was sequestrated in the smaller size fractions and more diversified zooplankton communities were observed, as indicated by the greater number of taxa with a relative dominance index larger than zero (see Fig. 7), which could indicate an abundance of alternative prey for shrimp larvae at these sites.

\section{CONCLUSION}

Physical processes that determine the degree of mixing in the water column could have a profound influence on the development of the zooplankton community and the planktonic food web (Holljgan et al. 1984, Kiørboe et al. 1990). In the cold waters of the GuIf of St. Lawrence, especially in spring, the density structure of the surface layer is largely controlled by salinity variation through freshwater runoff (Bugden et al. 1982). At the same time, the cold intermediate layer is the source of inorganic nutrients that initiate and sustain primary production in the spring (Sévigny et al. 1979). These observations resulted in the hypothesis that increases in freshwater runoff will enhance stratification, reduce mixing, and lower the magnitude of the phytoplankton standing crop produced during the vernal bloom period (Bugden et al. 1982). Reduction in the primary production will influence the zooplankton dynamics. Thus, we propose the hypothesis that survival of the first larval stage and the recruitment to the shrimp stocks is deterministically (negatively) influenced by high buoyancy fluxes (runoff), through adverse influences on phytoplankton and zooplankton productions, in the northern Gulf of St. Lawrence. However, in the Gulf of St. Lawrence most of the freshwater runoff flows into the northwest sector and also important is the winter ice-sheet covering most of the north and northeastern sectors of the Gulf from January to April (Koutitonsky \& Bugden 1991). Ice melt in early spring will contribute to the formation of strong density gradient that may accelerate early phytoplankton growth and biomass accumulation until exhaustion of the nutrient reserves (Veth et al. 1992). Furthermore, it has been proposed that ice algae production (prior to the open-water vernal bloom) constitutes a significant food resource for copepods and could enhance secondary production potential (Runge et al. 1991). Therefore, it appears that freshwater runoff (by reduction of phytoplankton standing crop) and ice coverage (by enhancement of secondary production) may influence the survival potential of shrimp larvae, in different and opposite ways, in the northern Gulf of St. Lawrence.

Acknowledgements. We thank the captain and crew of the MV 'Petrel- $V$ ' for their help and patience during the oceanographic mission. We also thank Mr Serge Gosselin and Ms Kathia Hebert for their efforts during the cruise and their assistance in the laboratory analyses. The reviews by 5 anonymous referees were also instrumental in improving the presentation of the manuscript.

\section{LITERATURE CITED}

Anger K, Harms J (1990) Elementa] (CHN) and proximate biochemical composition of decapod crustacean larvae. Comp Biochem Physiol 97B(1):69-80

Anger K, Harms J, Püschel C, Seeger B (1989) Physiological and biochemical changes during the larval development of a brachyuran crab reared under constant conditions in the laboratory. Helgoländer Meeresunters 43:225-244

Bugden GL, Hargrave BT, Sinclair MM, Tang CL, Therriault JC. Yeats PA (1982) Freshwater runoff effects in the marine environment: the Gulf of St. Lawrence example. Can Fish Aquat Sci Tech Rep 1078

Chandumpai A, Dall W. Smith DM (1991) Lipid-class composition of organs and tissues of the tiger prawn Penaeus esculentus during the moulting cycle and during starvation. Mar Biol 108:235-245

Cullen JJ, Stewart E, Renger E, Eppley RW, Winant CD (1983) Vertical motion of the thermocline, nitracline and chlorophyll maximum layers in relation to currents on the Southern California Shelf. J mar Res 41:239-262

Dall W, Chandumpai A, Smith DM (1993) The fate of some ${ }^{14} \mathrm{C}$-labelled dietary lipids in the tiger prawn Penaeus 
esculentus. Mar Biol 115:39-45

de Lafontaine Y, Demers S, Runge J (1991) Pelagic food web interactions and productivity in the Gulf of St. Lawrence a perspective. In: Therriault JC (ed) The Gulf of St Lawrence: small ocean or big estuary? Can Spec Publ Fish Aquat Sci 113:99-123

Fogarty MJ, Sissenwine MP, Cohen EB (1991) Recruitment variability and the dynamics of exploited marine populations. TREE 6:241--246

Holligan PM, Harris RP, Newell RC, Harbour DS, Head RN, Linley EAS, Lucas MI, Tranter PRG, Weekley CM (1984) Vertical distribution and partitioning of organic carbon in mixed, frontal and stratified waters of the English Channel. Mar Ecol Prog Ser 14:111-127

Hopkins CCE, Sargent JR, Nilssen EM (1993) Total lipid content, and lipid and fatty acid composition of the deepwater prawn Pandalus borealis from Balsfjord, northern Norway: growth and feeding relationships. Mar Ecol Prog Ser 96:217-228

Kiorboe T, Kaas H, Kruse B, Mohlenberg F, Tiselius P, Ertebjerg $G(1990)$ The structure of the pelagic food web in relation to water column structure in the Skagerrak. Mar Ecol Prog Ser 59:19-32

Kleppel GS, Holliday DV, Pieper RE (1991) Trophic interactions between copepods and microplankton: a question about the role of diatoms. Limnol Oceanogr 36:172-178

Koutitonsky VG, Bugden GL (1991) The physical oceanography of the Gulf of St. Lawrence: a review with emphasis on the synoptic variability of the motion. In: Therriault JC (ed) The Gulf of St. Lawrence: small ocean or big estuary? Can Spec Publ Fish Aquat Sci 113:57-90

Kvålseth TO (1991) Note on biological diversity, evenness, and homogeneity measures. Oikos 62:123-127

Laurence GC (1990) Growth, survival, and recruitment in large marine ecosystems. In: Sherman K, Alexander LM, Gold BD (eds) Large marine ecosystems: patterns. processes, and yields. American Association for the Advancement of Science, Washington, DC, p 132-149

Lieberman SH, Gilbert GD, Seligman PF, Dibelka AW (1984) Relationship between chlorophyll a fluorescence and underwater light transmission in coastal waters off Southern California. Deep Sea Res 31:171-180

Lovrich GA, Ouellet P (1994) Patterns of growth and triacylglycerol content in snow crab Chionoecetes opilio (Brachyura: Majidae) zoeal stages reared in the laboratory. Mar Biol 120:585-591

Murray DK (1985) Improved reproducibility and quantitative analysis of phospholipids by flame ionization detection. J Chromatogr 331:303-312

Nunes P (1984) Reproductive and larval biology of northern shrimp, Pandalus borealis Kroyer, in relation to temperature. PhD thesis, University of Alaska, Fairbanks

Ouellet P, Lefaivre D (1994) Vertical distribution of shrimp (Pandalus borealis) larvae in the Gulf of St. Lawrence; implications for trophic interactions and transport. Can J Fish Aquat Sci 51:123-132

Ouellet $\mathrm{P}$, Lefaivre D, Koutitonsky V (1990) Distribution of shrimp (Pandalus borealis) larvae and hydrographic pattern in the northern Gulf of St. Lawrence. Can J Fish Aquat Sci 47:2068-2078

This article was submitted to the editor
Ouellet P, Taggart CT, Frank KT (1992) Lipid condition and survival in shrimp Pandalus borealis larvae. Can J Fish Aquat Sci 49:368-378

Paul AJ, Paul JM, Shoemaker PA, Feder HM (1979) Prey concentrations and teeding response in laboratory-reared stage-one zoea of kıng crab, snow crab, and pink shrmp. Trans Am Fish Soc 108:440-443

Posgay A, Marak RR (1980) The MARMAP bongo zooplankton samplers. J Northwest Atl Fish Sci 1:91-99

Richardson K (1985) Plankton distribution and activity in the North Sea/Skagerrak-Kattegat frontal area in April 1984 Mar Erol Prog Ser 26:233-244

Runge JA (1985) Relationship of egg production of Calanus pacificus Brodsky to seasonal changes in phytoplankton availability in Puget Sound, Washington. Limnol Oceanogr 30:382-396

Runge JA, Therriault JC, Legendre L, Ingram RG, Demers S (1991) Coupling between ice microalgal productivity and the pelagic, metazoan food web in southeastern Hudson Bay: a synthesis of results. In: Sakshaug E, Hopkins CCE, Øritsland NA (eds) Proceedings from the Pro Mare Symposium on Polar Marine Ecology. Polar Res 10 325-338

Sévigny JM, Sinclair M, El-Sabh MI, Poulet S, Coote A (1979) Summer plankton distributions associated with the physical and nutrient properties of the northwestern Gulf of St Lawrence. J Fish Res Bd Can 36:187-203

Shepherd JG, Pope JG, Cousens RD (1984) Variations in fish stocks and hypotheses concerning their links with climate Rapp P-v Réun Cons int Explor Mer 185:255-267

Shumway SE, Perkins HC, Schick DF, Stickney AP (1985) Synopsis of biological data on pink shrimp, Pandalus borealis Kroyer, 1838. NOAA Tech Rep NMFS 30:1-57

Sokal RR, Rohlf FJ (1981) Biometry. WH Freeman \& Co, New York

Stickney AP, Perkins HC (1981) Observations on the food of the larvae of the northern shrimp, Pandalus borealis Krøyer (Decapoda, Caridea). Crustaceana 40:36-49

Taggart CT, Frank KT (1990) Perspectives on larval fish ecology and recruitment processes; probing the scales of relationships. In: Sherman K, Alexander LM, Gold BD (eds) Large marine ecosystems: patterns, processes, and yields. American Association for the Advancement of Science Washington, DC, p 151-164

Vance DE, Vance JE (1985) Biochemistry of lipids and membranes. The Benjamin/Cummings Publishing Company, Inc, Menlo Park, CA

Vandevelde T, Legendre L, Demers S, Therriault JC (1988) Interrelationship between in vivo fluorescence of phytoplankton and light beam transmission with reference to fluorescence yield. Can J Fish Aquat Sci 45:1508-1513

Veth C, Lancelot C, Ober S (1992) On processes determining the vertical stability of surface waters in the marginal ice zone of the north-western Weddell Sea and their relationship with phytoplanktor bloom development. Polar Biol $12: 237-243$

Wienberg R (1982) Studies on the influence of temperature, salinity, light, and feeding rate on laboratory reared larvae of deep sea shrimp. Pandalus borealis Kroyer 1838. Meeresforschung 29:136-153

Manuscript first received: May 10,1994

Revised version accepted: April 12, 1995 